\title{
Evaluation of Sunflower (Helianthus annuus L.), Sorghum (Sorghum bicolor L.) and Chinese Cabbage (Brassica chinensis) for Phytoremediation of Lead Contaminated Soils
}

\author{
Rodrick Hamvumba ${ }^{1}$, Mebelo Mataa ${ }^{1} \&$ Alice Mutiti Mweetwa ${ }^{2}$ \\ ${ }^{1}$ Department of Plant Sciences, School of Agricultural Sciences, University of Zambia, Zambia \\ ${ }^{2}$ Department of Soil Sciences, School of Agricultural Sciences, University of Zambia, Zambia \\ Correspondence: Alice Mutiti Mweetwa, Department of Soil Sciences, School of Agricultural Sciences, \\ University of Zambia, Box 32379, Lusaka, Zambia. Tel: 260-971-803-918. E-mail: alicemweetwa@yahoo.com
}

\author{
Received: February 28, 2014 Accepted: March 21, 2014 Online Published: March 25, 2014 \\ doi:10.5539/ep.v3n2p65 \\ URL: http://dx.doi.org/10.5539/ep.v3n2p65
}

\begin{abstract}
The problems associated with heavy metal contamination are widespread and are especially common in developing countries. A pot study was carried out to evaluate the effectiveness of Sunflower (Helianthus annuus), Sorghum (Sorghum bicolor) and Chinese cabbage (Brassica chinensis) at removing lead from the soil. Lead contaminated soils were collected from Kabwe near the old Lead mine and characterized for total and extractable lead, $\mathrm{pH}$, organic matter, texture and cation exchange capacity. The average total and extractable lead concentrations were 23313 and $5876 \mathrm{mg} / \mathrm{kg}$, respectively, in contaminated soil compared to 57.75 and 10.02 $\mathrm{mg} / \mathrm{kg}$ in uncontaminated soil. The contaminated soil was then diluted with uncontaminated soil to achieve five contamination levels of $5876,2500,1000,500$ and $10.02 \mathrm{mg} / \mathrm{kg}$. Test plants were grown for 10 weeks after which below and above ground dry biomass yields were determined and tested for lead concentration and uptake. Results from this study show that Chinese cabbage is more effective at lead uptake than Sunflower and Sorghum. Results also show that high soil lead concentration results in poor plant growth, low biomass yield and increased lead accumulation in plant tissue.
\end{abstract}

Keywords: Zambia, Kabwe, lead, phytoremediation, soil, contamination, mining, pollution

\section{Introduction}

Heavy metal contamination results mainly from anthropogenic activities such as mining and metal smelting. This contamination is a serious environmental problem that may threaten whole ecosystems and humans. Humans and wildlife are exposed to heavy metals through several pathways that may include contaminated drinking water and food, inhaling particulates and contaminated soil health (Qu, Ma, Yang, Bi, \& Huang, 2012; Ikenaka et al., 2010). Exposure to heavy metals such as lead have been shown to have several negative effects in humans. Examples of such effects include problems with coordination of muscles, nerve damage, brain damage, impaired hearing, stunted growth and mental retardation in children (United States Environmental Protection Agency [USEPA], 2013).

Currently, most studies are aimed at finding means of removing these heavy metals from the soil, and thus various methods have been suggested that include both ex-situ and in-situ methods. The ex-situ methods require the removal of polluted soil for treatment on or off site, and subsequent return of the treated soil to the original site. This follows that the conventional ex-situ methods rely on excavating, detoxifying and/or destroying the polluting agent using physical or chemical means in order to stabilize, solidify, immobilize or completely destroy the contaminant (Ghosh \& Singh, 2005). The in-situ methods which involve the destruction or transformation of the contaminant on site (Vandgrift, Reed, \& Tasker, 1992) are preferred to the ex-situ techniques because they are cheaper and have potentially reduced impact on the ecosystem.

Phytoremediation, through the technology of phytoextraction, is a concept of using plants to clean the environment (Prasad \& Freitas, 2003). This technology is suitable for in situ clean-up of toxic metal polluted sites (Vashegyi et al., 2005). Unlike organic compounds, metals cannot be degraded, and clean-up usually requires their removal from polluted sites. Phytoremediation has proved to be an effective way of removing the toxic metals from soil (Prasad \& Freitas, 2003). The application of this concept takes into account the 
importance of biodiversity that encompasses several agricultural, horticultural and wild metal accumulating plants. More than 400 plants that hyperaccumulate heavy metals, from different families, have so far been tested for their potential use in the decontamination of polluted sites. Of these families, Brassicaceae has been reported to have the largest number of hyperaccumulaters (Prasad \& Freitas, 2003). Phytoremediation strategies appear promising as a way to reduce lead contamination in soils and thereby minimize its potential hazardous effects.

In Zambia, lead was mined in Kabwe (Central Province). Mining activities started at the beginning of the $20^{\text {th }}$ century and continued for 90 years until 1994 when the mine was closed, and smelting and sulphuric acid production operations conducted discontinued (The World Bank Group, 2013). Kabwe ranks among the 10 most polluted places in the world (Blacksmith Institute, 2007) with over 300,000 of the total population being affected by contaminated soil by 2003 (The World Bank Group, 2013). A lot of effort has been made to determine the extent of heavy metal contamination of the soils, aquatic systems and plants in Kabwe and other mining areas in Zambia (Ikenaka et al., 2010; Tembo, Sichilongo, \& Cernak, 2006). On average, children's blood lead levels in Kabwe have been reported to be as high as 5 to 10 times the permissible WHO/EPA maximum of $10 \mu \mathrm{g} / \mathrm{dL}$ (Blacksmith Institute, 2007).

The objective of the study was to determine the effectiveness of Sorghum bicolor L., Brassica chinensis and Helianthus annuиs L. in reducing concentrations of lead in contaminated soils from Kabwe. Specifically, the study evaluated the growth of and uptake of lead by Sorghum bicolor L., Brassica chinensis and Helianthus annuиs L. in lead contaminated soils.

\section{Method}

\subsection{Soil Sample Collection}

The lead contaminated soil was collected from a location near the former Lead Mine in Kabwe District. The lead contaminated soil was then characterized to determine selected physical and chemical properties using the methods described below.

\subsection{Characterization of the Soil}

The following methods were used to characterize the soil used in the study.

\subsubsection{Particle Size Distribution}

Particle size analysis of the fine earth fraction was determined using the hydrometer method (Day, 1965); air dried soils (50 grams) were weighed in triplicate and placed in the dispersing cups. Fifty milliliters of calgon (sodium hexametaphosphate) was then added and the cups filled with tap water to the half way mark. The cups were stirred continuously for five minutes. The suspension was transferred into a sedimentation cylinder using a stream of tap water, the cylinder filled to the $1000 \mathrm{ml}$ mark. A plunger was used to mix the contents thoroughly, after 20 seconds the hydrometer was lowered carefully into the cylinder and the density of the suspension read. The temperature was read using a thermometer. After two hours the density and temperature were read again and the particle size distribution analyzed.

\subsubsection{Determination of Soil Organic Matter}

The Walkley and Black Method was used to determine organic matter (Olsen \& Sommers, 1982); One gram of air dried soil was weighed and placed in a conical flask, then $10 \mathrm{ml}$ of $1 \mathrm{~N} \mathrm{~K}_{2} \mathrm{Cr}_{2} \mathrm{O}_{7}$ was added. Twenty milliliters of concentrated $\mathrm{H}_{2} \mathrm{SO}_{4}$ was rapidly added to the conical flask by directing the stream into the suspension using an automatic pipette. The conical flask was then swirled vigorously for a minute. The conical was stored in the fume hood for 30 minutes. Afterwards $150 \mathrm{ml}$ of distilled water was added followed by $10 \mathrm{ml}$ of concentrated $\mathrm{H}_{3} \mathrm{PO}_{4}$. Ten drops of diphenylamine indicator solution was added to the conical flask and it was titrated with Iron (II) Sulphate.

\subsubsection{Determination of Soil $\mathrm{pH}$}

To determine $\mathrm{pH}$, the electronic $\mathrm{pH}$ meter was used (Mclean, 1982); $10 \mathrm{~g}$ of air dry Lead contaminated soils was placed in a $50 \mathrm{~cm}^{3}$ beaker and $25 \mathrm{~cm}^{3} 0.01 \mathrm{M} \mathrm{CaCl}_{2}$ added. Each mixture was placed on shaker for 30 minutes and $\mathrm{pH}$ determined using a $\mathrm{pH}$ meter.

\subsubsection{Determination of the Effective Cation Exchange Capacity of the Soil}

\subsubsection{Determination of the Exchangeable Acidity}

To determine the exchangeable acidity, the $\mathrm{NaOH}$ titration method was used (Mclean, 1982); $10 \mathrm{~g}$ air dry soil was weighed and put into a $250 \mathrm{~cm}^{3}$ Erlenmeyer flask, $100 \mathrm{~cm}^{3}$ of $1 \mathrm{M} \mathrm{KCl}$ was then added and covered with a rubber stopper. The conical flask was shaken for 1 hour and then the suspension filtered and the filtrate collected 
in a beaker. A volume of $25 \mathrm{~cm}^{3}$ of $\mathrm{KCl}$ extract was pipetted into a $250 \mathrm{~cm}^{3}$ conical flask and approximately 100 $\mathrm{cm}^{3}$ of distilled water was added. To the same flask, 5 drops of phenolphthalein indicator was added to the solution with a standard $0.01 \mathrm{M} \mathrm{NaOH}$ solution to a permanent pink end point. The amount of base used was equivalent to the exchangeable acidity in the aliquot taken.

\subsubsection{Extraction of Exchangeable Bases}

To determine the exchangeable bases, the ammonium acetate method was used (Thomas, 1982); $10 \mathrm{~g}$ of air dry soil was weighed and passed through a $2 \mathrm{~mm}$ sieve and put on a No 42 Whitman filter paper. Some $25 \mathrm{ml}$ of $1 \mathrm{~N}$ $\mathrm{NH}_{4} \mathrm{OAc}$ was added four times, the filtrate was removed and the soil was then rinsed with Ethanol four times as well. The rinsing was repeated and $100 \mathrm{ml}$ of $2 \mathrm{M} \mathrm{KCl}$ was added. Concentrations of $\mathrm{K}^{+}, \mathrm{Ca}^{2+}, \mathrm{Mg}^{2+}$ and $\mathrm{Na}^{+}$ were determined using the Atomic Absorption Spectroscopy (AAS).

\subsubsection{Determination of Total Lead in the Soil}

To determine the total concentration of lead in the soil, the Aqua Regia method was used; $1.0 \mathrm{~g}$ of lead contaminated soil was weighed using an electronic balance and to which $18 \mathrm{ml}$ of $\mathrm{HCl}$ and $6 \mathrm{ml} \mathrm{HNO}_{3}$ were added. The sample was allowed to digest on a hot plate until enough of the solution had evaporated. The sample was then cooled, $18 \mathrm{ml}$ of $\mathrm{HCl}$ and $6 \mathrm{ml}$ of $\mathrm{HNO}_{3}$ added again. The mixture was brought to $50 \mathrm{ml}$ volume using distilled water and amount of total Lead determined using AAS.

\subsubsection{Determination of Extractable Lead Using $0.5 \mathrm{M} \mathrm{HNO}_{3}$}

To determine extractable lead, the Nitric Acid method was used; $20 \mathrm{~g}$ of each soil sample was weighed using an electronic balance and to which $40 \mathrm{~cm}^{3}$ of $0.5 \mathrm{M} \mathrm{HNO}_{3}$ was added in order to extract only the Lead that may be soluble for plant uptake. The mixture was allowed to shake for 2 hours, afterwards it was filtered through No 42 Whitman filter paper and amount of extractable Lead determined using the AAS.

\subsection{Green House Experiment}

A greenhouse crop trial with 5 levels of lead contamination (Table 1) and 3 crop species (Chinese cabbage, Sunflower and Sorghum) was set up in a Completely Randomized Design (CRD) and replicated four times. The lead contaminated soil was diluted to 43,20 and $9 \%$ of the original lead concentration using ordinary soils from the Field Station at the University of Zambia. The dilution was done to monitor the performance of the different plant species in varying levels of lead in the soil. The dilutions were made based on the concentration of extractable lead in both contaminated and ordinary soil samples. The soils (ordinary soil and lead contaminated soil) were thoroughly mixed to ensure uniform distribution of Lead in each pot.

Table 1. Dilutions of soil for greenhouse crop trials for Chinese cabbage, sunflower and sorghum

\begin{tabular}{ccc}
\hline Soil Sample & Extractable Lead (mg/kg) & Total Lead (mg/kg) \\
\hline Undiluted & 5876 & 23313 \\
Dilution 1 (43\%) & 2500 & 11500 \\
Dilution 2 (20\%) & 1000 & 4600 \\
Dilution 3 (9\%) & 500 & 2300 \\
Control & 10 & 58 \\
\hline
\end{tabular}

The Milika, Chihili and Sima crop varieties of sunflower, Chinese cabbage and sorghum, respectively, were used for this trial. Seeds were sown directly to the appropriate depth. Basal and Top dressing fertilizer were applied at recommended rates for each plant species and in relation to plant density. The plants were grown for 10 weeks after which the shoots and roots were harvested and dried.

\subsection{Determination of Lead in the Leaves of Sorghum, Sunflower and Chinese Cabbage}

To determine lead concentrations in the leaves of all plants, approximately $1 \mathrm{~g}$ of each plant sample biomass was weighed using a sensitive electronic balance and ashed at $500{ }^{\circ} \mathrm{C}$ to which $10 \mathrm{ml} 1 \mathrm{~N} \mathrm{HNO}_{3}$ was added, filtered and brought to volume of $100 \mathrm{ml}$ by adding distilled water. Concentrations of lead were then determined by AAS. Lead uptake was calculated from the Lead concentrations by multiplying the concentration by the total dry mass of the crop. 


\title{
2.5 Statistical Analysis
}

To assess whether there were significant differences among various treatment effects, Analysis of Variance was carried out.

\section{Results}

\subsection{Soil Characterization}

The characteristics of uncontaminated and lead contaminated soils are presented in Table 2. The lead contaminated soil was slightly acidic (pH 6.49) with a loamy sand texture and high concentration of Lead exceeding the US EPA's permissible soil Lead content in bare soil of $400 \mathrm{mg} / \mathrm{kg}$ (USEAP, 2001). The ordinary soil had a neutral soil $\mathrm{pH}(\mathrm{pH} 7.15)$ with a sandy loam texture, low organic matter content (1.4\%) and low soil lead concentration. The organic matter content was higher $(3.36 \%)$ in the contaminated soil than that of the ordinary soil, perhaps due to high presence of grass root during the time of soil collection. In both soils, the ECEC was moderately low, being 5.72 and $6.53 \mathrm{meq} / 100 \mathrm{~g}$ for the lead contaminated and the normal soils, respectively.

Table 2. Selected chemical and physical characteristics of soil

\begin{tabular}{ccccccc}
\hline Soil sample & Soil $\mathrm{pH}$ & $\begin{array}{c}\text { Extractable Lead } \\
(\mathrm{mg} / \mathrm{kg})\end{array}$ & $\begin{array}{c}\text { Total Lead } \\
(\mathrm{mg} / \mathrm{kg})\end{array}$ & OM $(\%)$ & Texture & $\begin{array}{c}\text { ECEC } \\
(\mathrm{meq} / 100 \mathrm{~g})\end{array}$ \\
\hline Contaminated & 6.49 & 5876 & 23313 & 3.36 & Loamy sand & 5.72 \\
Uncontaminated & 7.15 & 10.02 & 57.75 & 1.4 & Sandy loam & 6.53 \\
\hline
\end{tabular}

\subsection{The Effect of Lead on Plant Growth}

In general, an inverse relationship was observed between plant growth and soil lead concentration (Figure 1). Poor plant growth in all species was observed at high soil lead concentrations as there was poor root and shoot growth (Figure 1). Complete failure of sunflower to grow at high lead concentrations was also observed.

\subsection{Below Ground Biomass Yield at Harvest}

Sunflower produced the highest below ground biomass followed by sorghum and lastly Chinese cabbage. In all the three plant species, an increase in biomass was observed as the concentrations of lead among treatments declined (Figure 2). The results show that sunflower, which has a bigger growth form, had a larger below ground biomass yield than the other two crops. Significant differences were observed for each crop species among the first three soil treatments containing 5867, 2500, and $1000 \mathrm{mg} / \mathrm{kg}$ of lead as shown in Figure 2.

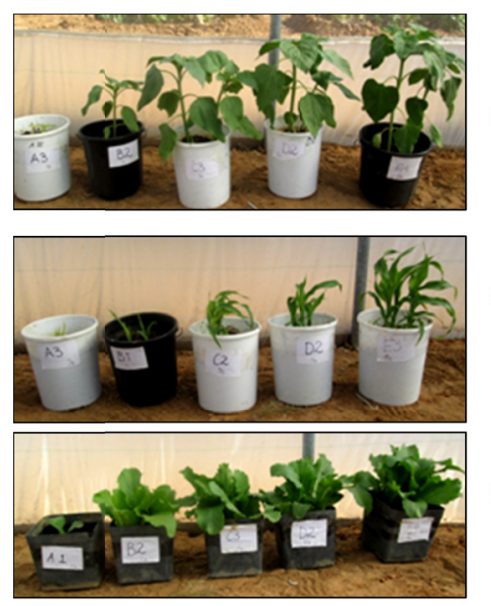

\author{
Treatments (Total lead \\ mg/kg soil: \\ A: 23313 \\ B: 11500 \\ C: 4600 \\ D: 2300 \\ E: 58
}

SORGHUM

CHINESE CABBAGE

Figure 1. Plant growth of sunflower (Helianthus annuus), sorghum (Sorghum bicolor) and Chinese cabbage (Brassica chinensis) at 6 weeks after sowing 


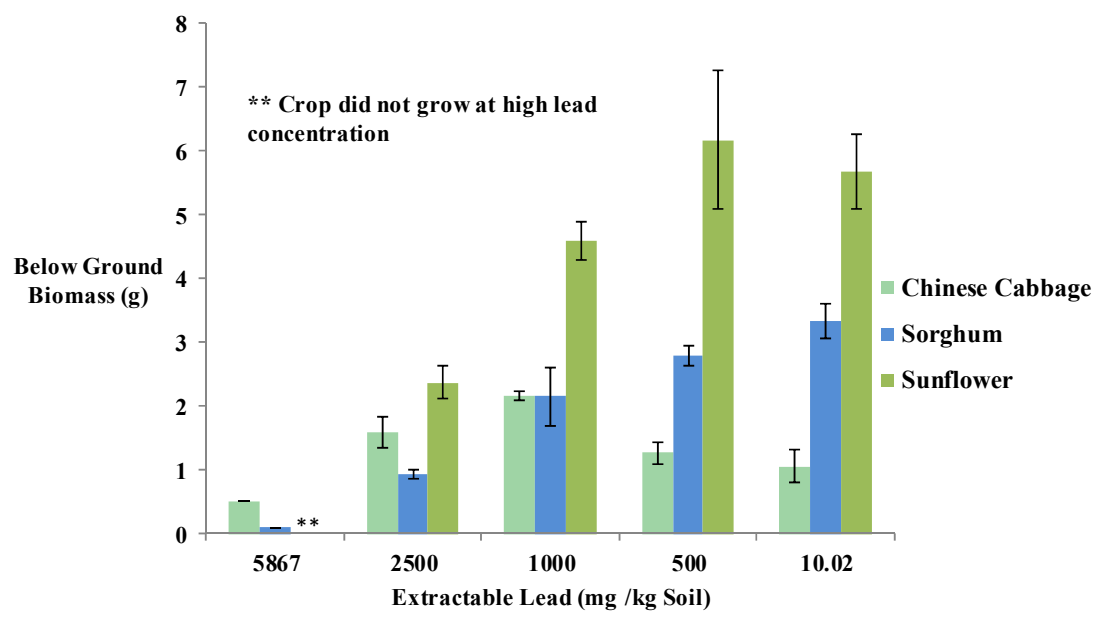

Figure 2. Below ground biomass yield at harvest of sunflower (Helianthus annuus), sorghum (Sorghum bicolor) and Chinese cabbage (Brassica chinensis)



Figure 3. Above ground biomass yield at harvest of sunflower (Helianthus annuus), sorghum (Sorghum bicolor) and Chinese cabbage (Brassica chinensis var)

\subsection{Above Ground Biomass Yield at Harvest}

At soil lead concentrations where it was able to grow, sunflower produced the highest above ground biomass followed by Chinese cabbage and sorghum (Figure 3). Sorghum had the lowest biomass yield and showed severe signs of stunted growth due lead toxicity. Generally, an inverse relationship was observed as shoot biomass yield reduced with increase in soil lead concentrations among treatments.

\subsection{Lead Concentrations in Below Ground Tissue at Harvest}

Figure 4 shows the lead concentrations in below ground tissue for all the 3 plant species grown in soil with different lead levels. In all of the plants analyzed, the root portion of the plant showed the highest levels of lead, followed by the shoots, in which the levels were undetectable (for sunflower and sorghum). Chinese cabbage accumulated more lead in the roots than sunflower and sorghum at all the levels of lead contamination, except for the uncontaminated soil. With Chinese cabbage, there was a linear increase in lead concentration in the roots as the soil lead concentration increased. Sunflower showed a slight constant or uniform Lead accumulation from treatment 2500 to $500 \mathrm{mg} / \mathrm{kg}$.

The results from this study suggest that Chinese cabbage is more tolerant to high soil lead concentration than sunflower and sorghum. Sunflower proved to be very sensitive to high lead levels in soils as it failed to grow when extractable lead concentrations were high $(5867 \mathrm{mg} / \mathrm{kg})$ and its growth was very poor. 


\subsection{Lead Concentrations in Above Ground Tissue at Harvest- Chinese Cabbage}

Lead concentrations in the above ground tissue in Chinese cabbage increased with increase in soil lead concentration (Figure 5). A drastic decrease of Lead content in the shoots was observed between 5876 to 2500 $\mathrm{mg} / \mathrm{kg}$ showing a significant difference in the accumulation of lead between the two treatments. An exponential decrease of lead content in shoots of Chinese cabbage was observed in treatments 5876 to $10.02 \mathrm{mg} / \mathrm{kg}$ as well. However, lead in the shoots of sunflower and sorghum was at levels below the experimental limit of detection which was $0.5 \mathrm{mg} / \mathrm{kg}$.

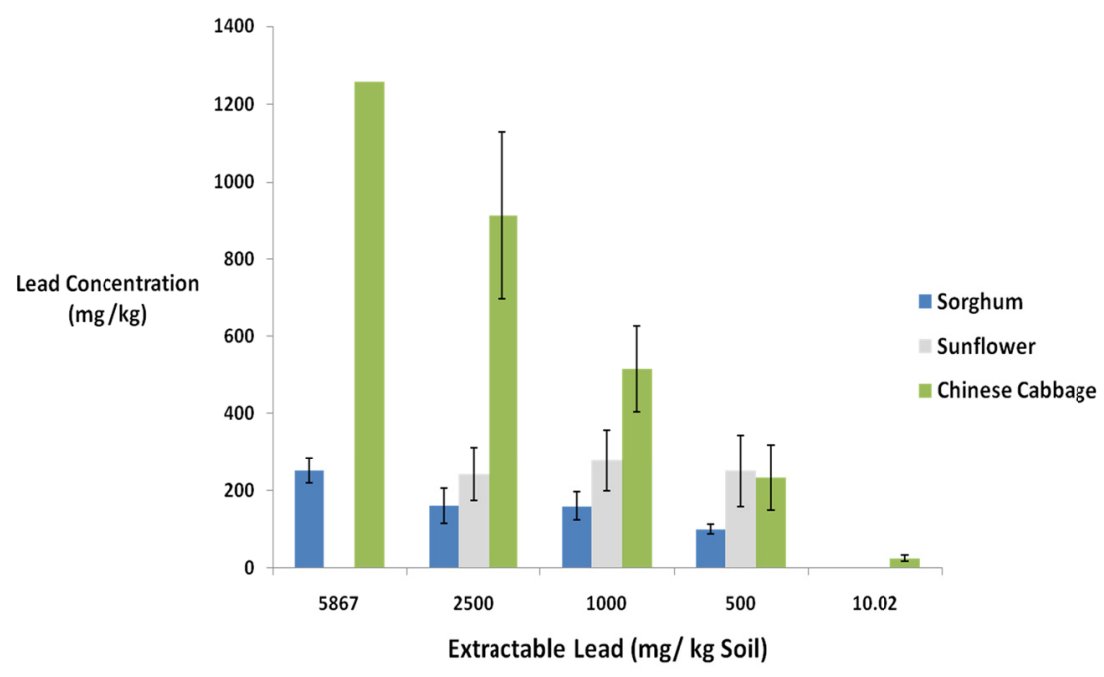

Figure 4. Lead concentrations in below ground tissue at harvest of sunflower (Helianthus annuus), sorghum (Sorghum bicolor) and Chinese cabbage (Brassica chinensis var)

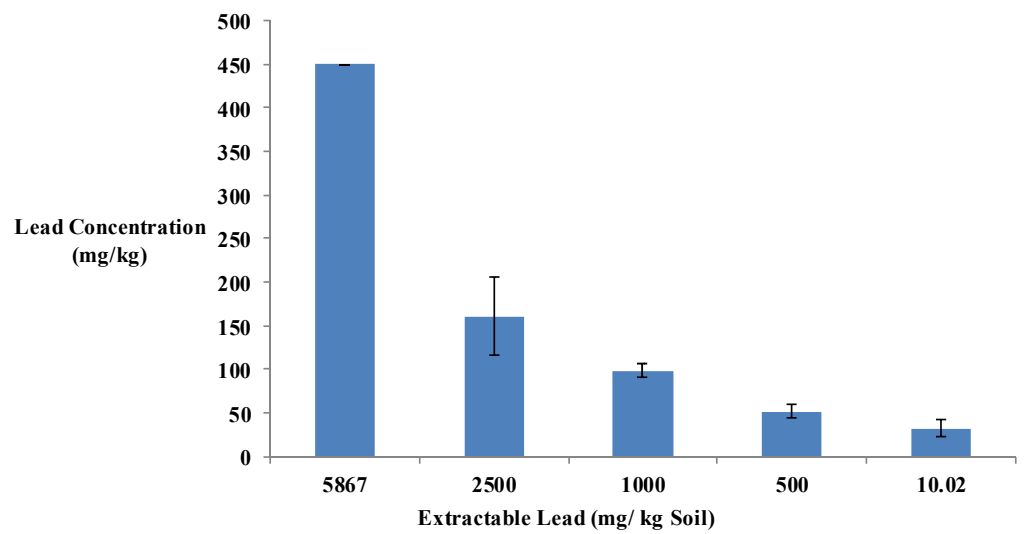

Figure 5. Lead concentrations in above ground tissue of cabbage (Brassica chinensis) at harvest

\subsection{Lead Uptake in Above Ground Tissue at Harvest- Chinese Cabbage}

Lead uptake was derived from the lead concentrations and biomass yields of the tissues (Figure 6). The results show that uptake of Lead by Chinese cabbage increased with the increase in soil extractable lead concentration. However, Chinese cabbage showed signs of uptake threshold as in treatment 5876 and $2500 \mathrm{mg} / \mathrm{kg}$ the total lead uptake in both treatments was almost the same. Among treatments, there were significant differences with regards to total uptake of Lead. The mass of total Lead uptake in pots by Chinese cabbage among the different treatments is shown in Figure 6. 


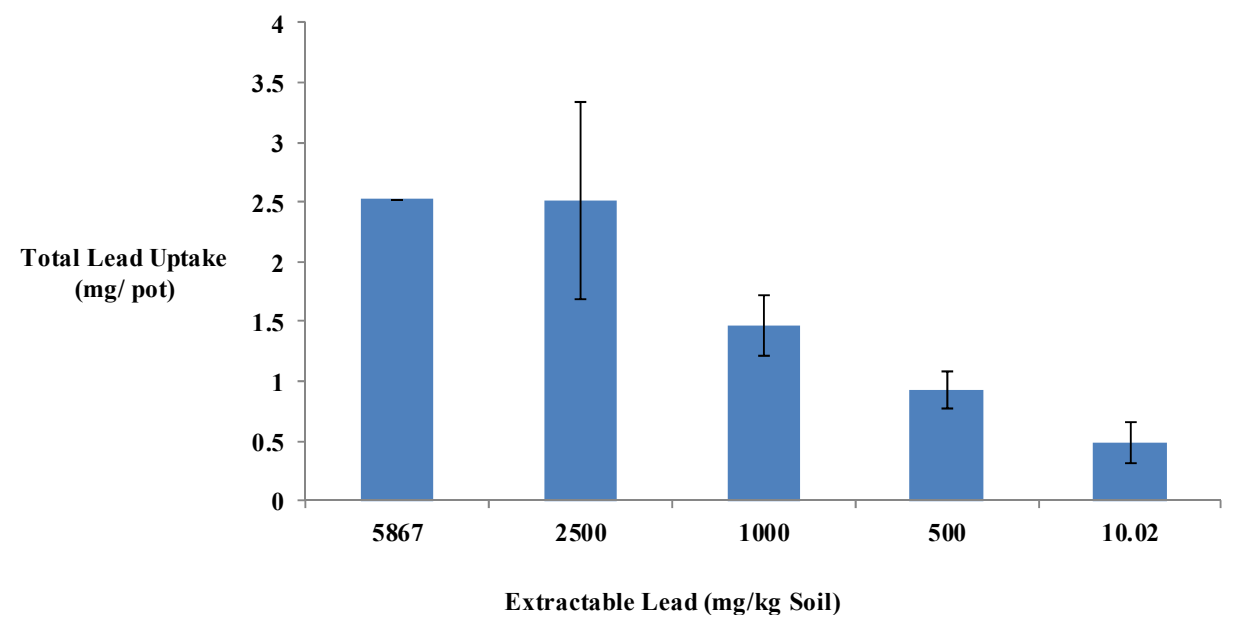

Figure 6. Lead uptake in above ground tissue at harvest (10 weeks) for Chinese cabbage (Brassica chinensis)

\section{Discussion}

Chinese cabbage, sunflower and sorghum all showed a poor growth pattern as the concentration of Lead in the soil increased among treatments. The observed inverse relationship between plant growth and soil lead concentration could be attributed to the direct negative effects of lead on plants (Figure 1). Symptoms of lead toxicity at higher lead levels included stunted growth and chlorosis. Previously, Sharma and Dubey (2005) noted that excess lead causes a number of toxicity symptoms in plants such as stunted growth, chlorosis and blackening of the root system, this agrees with the observations of this study. Alternatively, lead in the soil has been shown to be able to complex other plant nutrients such as phosphorus, thereby rendering them both unavailable for uptake (Xie, Wang, Sun, \& Li, 2006). It is possible that plants suffered phosphorus deficiencies contributing to poor plant growth i.e. stunting, even if the classic purple discoloration of leaves was not observed. Sunflower was more sensitive to high concentrations of lead in the soil to the extent that plants failed to grow up to harvest. However, this observation was rather unexpected as sunflower together with other species of the family Asteraceae have been proposed to be hyperaccumulators of heavy metals (Prasad \& Freitas, 2003). This observation could suggest that a threshold of lead contamination exists above which plants cannot survive. High soil concentrations of lead have been shown to reduce seed germination, root and shoot length, tolerance index and dry mass of roots and shoots of rice (Mishra \& Choudhuri, 1998). This could explain the observed growth patterns and the complete failure of sunflower seeds to germinate in soils with high levels of lead.

According to Seregin and Ivanov (2001), lead phytotoxicity leads to inhibition of enzyme activities, disturbed mineral nutrition, water imbalance, change in hormonal status and alteration in membrane permeability. These disorders upset the normal physiological activities of the plant and would result in loss of biomass yield as observed in this study (Figure 3). According to Xiong (1998), Brassica pekinensis belonging to the same family as Chinese cabbage (Brassicaceae) accumulated unusually high contents of lead in the root and shoot tissues. The results from this study suggest that Chinese cabbage is more tolerant to high soil lead concentrations than sunflower and sorghum. Sunflower proved to be very sensitive to high lead levels in soils as it failed to grow when extractable lead concentrations were high $(5867 \mathrm{mg} / \mathrm{kg})$ and its growth was very poor.

According to Sharma and Dubey (2005), roots can take up significant quantities of lead whilst greatly restricting its translocation to above ground parts as observed in Sunflower and Sorghum. Therefore, it can be suggested that Chinese cabbage was more effective at accumulating lead in the shoots than sunflower and sorghum. Though this may seem to be a good characteristic of Chinese cabbage, most researchers recommend that plants appropriate for phytoremediation should accumulate metals only in the roots (Prasad \& Freitas, 2003).

Chinese cabbage appeared to be more efficient at the uptake of lead from the soil than sorghum and sunflower. Prasad and Freitas (2003) noted that it is the combination of high metal accumulation and high biomass production that results in the most efficient metal removal. From the results obtained, soil lead concentration affects the amount of plant biomass produced; reducing with an increase in soil lead concentration. Lead accumulation in plant tissue increases with increase in soil lead concentration as observed in sunflower, sorghum and Chinese cabbage among the different treatments. It can be concluded that Chinese cabbage is capable of taking up lead from the soil and that it is more efficient than sunflower and sorghum. However, indications are 
that this would only be applicable to sites that contain low to moderate levels of lead contamination because plant growth is not sustained in heavily contaminated soils.

Based on the observations from the current study, and in order to get more insightful observations, plants should be allowed to grow to full maturity. This will allow for partitioning of plant tissue so as to determine how much lead would be accumulated in each plant part. Secondly, field experiments should be done to evaluate the response of plants grown directly in the sites of contamination. Greenhouse conditions are not truly representative of field conditions and the results from such studies are only indicative. In the field, plants are subjected to less than optimal conditions and thus may have different morphological and physiological responses.

\section{Acknowledgements}

We wish to acknowledge the technicians in the Department of Soil Science and Mr. V. Shitumbanuma for their technical input into this study.

\section{References}

Blacksmith Institute. (2007). The world's worst polluted places (pp. 1-69). The top ten of the dirty thirty, Blacksmith Institute, New York, USA. Retrieved from http://www.worstpolluted.org

Day, P. R. (1965). Particle size fractionation and particle size analysis. In C. A. Black (Ed.), Methods of soil analysis. Agronomy, 9, 545-567.

Ghosh, M., \& Singh S. P. (2005). A Review on Phytoremediation of Heavy Metals and Utilization of its Byproducts. Applied Ecology and Environmental Research, 3(1), 1-18, Retrieved from http://ecology.kee.hu/pdf/0301_001018.pdf

Ikenaka, Y., Nakayama, S. M. M., Muzandu. K., Choongo, K., Teraoka, H., Mizuno, N., \& Ishizuka, M. (2010). Heavy metal contamination of soil and sediment in Zambia. African Journal of Environmental Science and Technology, 4(11), 729-739. http://dx.doi.org/10.4314\%2Fajest.v4i11.71339

Mclean, E. O. (1982). Soil pH and lime requirement. In A. L. Page, R. H. Miller, \& D. R. Keeney (Eds.), Methods of soil analysis. Part 2. Chemical and microbiological properties. (2nd ed.). Agronomy, 9, 99-223.

Mishra, A., \& Choudhuri, M. A. (1998). Amelioration of lead and mercury effects on germination and rice seedling growth by antioxidants. Biologia. Plantarum, 41, 469-473. http://dx.doi.org/10.1023/A:1001871015773

Olsen, S. R., \& Sommers, L. E. (1982). Phosphorus. In A. L. Page, R. H. Miller, \& D. R. Keeney (Eds.), Methods of soil analysis: Part 2- Chemical and microbiological properties. (2nd ed., pp. 403-430). Madison, WI: American Society of Agronomy.

Prasad, M., \& Freitas, H. O. (2003). Metal hyperaccumulation in plants- Biodiversity prospecting for phytoremediation technology. Electronic Journal of Biotechnology, 6(3). http://dx.doi.org/10.2225/vol6-issue3-fulltext-6

Qu, C. S., Ma, Z. W., Yang, J., Bi, J., \& Huang, L. (2012). Human exposure pathways of heavy metals in a lead-zinc mining area, Jiangsu Province, China. PLoS ONE, 7(11), e46793. http://dx.doi.org/10,1371/journal.pone.00467.

Seregin, I. V., \& Ivaniov, V. B. (2001). Physiological aspects of cadmium and lead toxic effects on higher plants. Russian Journal of Plant Physiology, 48, 523-544. http://dx.doi.org/ 10.1023/A: 1016719901147

Sharma, P., \& Dubey, R. S. (2005). Lead toxicity in plants. Brazilian. Journal of Plant Physiology, 17(1) 35-52. http://dx.doi.org/10.1590/S1677-04202005000100004

Tembo, B. D., Sichilongo, K., \& Cernak, J. (2006). Distribution of copper, lead, cadmium and zinc concentrations in soils around Kabwe town in Zambia. Chemosphere, 63(3), 497-501. http://dx.doi.org/10.1016/j.chemosphere.2005.08.002

The World Bank Group. (2013). Copperbelt Environment Project tackles the lead and uranium danger in Zambia. Retrieved February 28, from http://web.worldbank.org/WBSITE/EXTERNAL/NEWS/0,,contentMDK:23169108 menuPK:141310 pag ePK:34370 piPK:34424 theSitePK:4607,00.html

Thomas, G. W. (1982). Exchangeable cations. In A. L., Page (Ed.), Methods of soil anaylsis. Part 2. (2nd ed). Agronomy Monograph 9, American Society of Agronomy, Madison, WI. 
USEPA. (2001). Lead; Identification of dangerous levels of lead. Final Rule. Federal register, 40 CRF Part 745. Retrieved February 28, 2014, from http://epa.gov/superfund/lead/products/rule.pdf

USEPA. (2013). Human health and lead. Retrieved February 28, 2014, from http://www.epa.gov/superfund/lead/health.htm

Vandgrift, G. F., Reed, D. T., \& Tasker I. R. (Eds.). (1992). Environmental remediation: Removing organic and metal ion pollutants. ACS Symposium Series 509. Washington DC: ACS

Vashegyi, A., Mezôsi, G., Barta, K., Farsang, A., Dormány, G., Bartha, B., \& Erdei, L. (2005). Phytoremediation of heavy metal pollution: A case study. Acta Biologica Szegediensis, 49(1-2), 77-79. Retrieved from http://www2.sci.u-szeged.hu/ABS/2005/Acta\%20HP/4977.pdf

Xie, Z. M., Wang, B. L., Sun, Y. F., \& Li, J. (2006). Field demonstration of reduction of lead availability in soil and cabbage (Brassica chinensis L.) contaminated by mining tailings using phosphorus fertilizers. Journal of Zhejiang University Science B, 7(1), 43-50. http://dx.doi.org/ 10.1631/jzus.2006.B0043

Xiong, Z. T. (1998). Lead uptake and effects on seed germination and plant growth in a lead hyperaccumulatorBrassica pekinensis Rupr. Bulletin of Environmental Contamination and Toxicology, 60, 285-291. http://dx.doi.org/ 10.1007/s001289900623

\section{Copyrights}

Copyright for this article is retained by the author(s), with first publication rights granted to the journal.

This is an open-access article distributed under the terms and conditions of the Creative Commons Attribution license (http://creativecommons.org/licenses/by/3.0/). 